\title{
Histological Changes in the Small Intestinal Epithelium in Fattening Pigs Fed Selected Feed Additives
}

\author{
Anna Rekiel ${ }^{1}$, Wojciech Bielecki², Justyna Więcek ${ }^{1}$, Józef Kulisiewicz ${ }^{1}$ \\ ${ }^{1}$ Department of Animal Breeding, Faculty of Animal Sciences, Warsaw University of Life Sciences, Poland \\ ${ }^{2}$ Department of Clinical Sciences, Faculty of Veterinary Medicine, \\ Warsaw University of Life Sciences, Poland
}

Received December 30, 2008

Accepted September 8, 2009

\begin{abstract}
The production experiment was conducted on 48 fattener pigs fed complete diets supplemented with the antibiotic flavomycin (group C), the probiotic Bactocell ${ }^{\circledR}$ (Pedicoccus acidilactici, strain MA $18 / 5 \mathrm{M}$ ) at the amount of $0.01 \%$ in the first and second stage of fattening (group E1), and the prebiotic BIO-MOS ${ }^{(S a c c h a r o m y c e s ~ c e r e v i s i a e, ~ s t r a i n ~ 1026) ~ a t ~ t h e ~ a m o u n t ~ o f ~} 0.1 \%$ in the first stage of fattening (group E2). Serial sections of the duodenum, jejunum and ileum were prepared post mortem. Haematoxylin and eosin and immunohistochemical (Ki-67, PCNA) staining procedures were performed. The effect of the feed additives on the morphological characteristics and proliferation capacity of small intestinal crypt epithelium varied when mitotic indices in groups were compared. In comparison with group $\mathrm{C}$, the enterocytes were higher in group E2 in the jejunum $(P \leq 0.01)$ and smaller in the ileum $(P \leq 0.01)$. Administration of the Ki-67 antibody resulted in fewer positive reactions in the jejunum in group E1 than in group $\mathrm{C}(P \leq 0.01)$. Enterocyte proliferation in crypt epithelium decreased after the administration of the probiotic or the prebiotic vs. the antibiotic, but the absence of significant differences between the groups may suggest that these feed additives have no adverse effect on the mucosal epithelial cells.
\end{abstract}

Small intestine, mitotic index, PCNA, Ki-67

Morphometric and functional changes in the intestinal mucosa are caused by nutritional factors (Schweiger et al. 2003; Domeneghini et al. 2004; Babinska et al. 2005). Various bacterial populations in the gastrointestinal tract are capable of modifying intestinal microstructures and the immune system (Vitini et al. 2000; Lata et al. 2006). Histological research investigates the effect of various diets (e.g. milk diet, diet with a varied share of faba beans) and dietary systems (restricted or ad libitum) on the morphometric characteritics of the intestines (Mroz 2001). It was found that feed additives (probiotics and prebiotics) do not have an adverse effect on the morphometric characteristics of the intestines (Budiño et al. 2005; Reiter 2006). Dietary factors increase the height of intestinal villi as well as the number and depth of crypts (Mroz 2001). Crypts are responsible for the proliferation of epithelial cells, the production of defensins - antibacterial immunity agents, and endocrine substances, such as chomogranin A. Defence reactions are stimulated in crypts, supporting antibody production and phagocytosis (Manning and Gibson 2004). Diet components, fibre content and the applied dietary method and feeding system affect intestinal microflora (Rekiel and Gajew ska 2006), as well as the proliferation and secretory activity of intestinal crypt enterocytes (McCullogh et al. 1998; Ekelund and Ekblad 1999; Schweiger et al. 2003; Piel et al. 2005; Van Nevel et al. 2005).

The objective of this study was to determine the impact of antibiotics, probiotics and prebiotics on the morphometric characteristics and proliferation activity of crypt enterocytes in the small intestine of fatteners.

\section{Materials and Methods}

The experiment was conducted on 48 hybrid fatteners [(Polish Large White $\times$ Polish Landrace $) \times$ Duroc and (Polish Large White $\times$ Polish Landrace) $\times$ Belgian Landrace) (1:1); gilts and young hogs (1:1)] divided into three

Address for correspondence:

Prof. dr hab. Anna Rekiel

Department of Animal Breeding, Faculty of Animal Sciences

Warsaw University of Life Sciences, Ciszewskiego 8, Warsaw 02-786, Poland
Phone: (+48) 0225936561

Fax: (+48) 0225936554

e-mail: anna rekiel@sggw.pl

http://www.vfu.cz/acta-vet/actavet.htm 
equal groups: control $(\mathrm{C})$ and experimental - E1 and E2 (each $\mathrm{n}=16)$. The animals were clinically healthy and had been treated for parasites prior to fattening. They were kept individually throughout the experiment. During a two-stage fattening process $(21-56 \mathrm{~kg}, 56-100 \mathrm{~kg})$, the feed was dosed individually in line with the observed standards (Polish Norm of Pigs Nutrition 1993). Group C pigs were fed a complete diet supplemented with 5\% flavomycin premix (100 mg per kg), and group E1 and E2 pigs were fed a premix without the antibiotic (Table 1). At the first and second stage of fattening (103 days), group E1 pigs received mixed feed containing $0.01 \%$ of the probiotic Bactocell ${ }^{\mathbb{P}}$ (Lallemand Animal Nutrition) (Pedicoccus acidilactici, strain MA18/5M). Group E2 pigs

Table 1. Composition of dites

\begin{tabular}{|l|c|c|c|c|c|c|c|}
\hline \multirow{3}{*}{ Item (per cent) } & \multicolumn{7}{|c|}{ Group } \\
\cline { 2 - 8 } & \multicolumn{2}{|c|}{ Control } & \multicolumn{2}{c|}{ Experimental I } & \multicolumn{2}{c|}{ Experimental II } \\
\cline { 2 - 8 } & \multicolumn{5}{|c|}{ Period } \\
\cline { 2 - 8 } & I & II & I & II & I & II \\
\hline Ground barley & 53.15 & 58.74 & 53.23 & 58.73 & 53.05 & 58.74 \\
\hline Ground wheat & 25 & 25 & 25 & 25 & 25 & 25 \\
\hline Soybean meal & 11.5 & 6 & 11.5 & 6 & 11.5 & 6 \\
\hline Meat bone meal & 5 & 5 & 5 & 5 & 5 & 5 \\
\hline Premix with antibiotic & 5 & 5 & - & - & - & - \\
\hline Premix without antibiotic & ${ }^{2}$ & - & - & 5 & 5 & 5 & 5 \\
\hline Bactocell* & - & - & 0.01 & 0.01 & - & - \\
\hline BIO-MOS** & - & - & - & - & 0.1 & - \\
\hline L-Lysine $^{*}$ & 0.3 & 0.26 & 0.3 & 0.26 & 0.3 & 0.26 \\
\hline DL-Methionine & 0.05 & - & 0.05 & - & 0.05 & - \\
\hline
\end{tabular}

Composition of $1 \mathrm{~kg}$ of premix Lidermix T 5\%: ${ }^{1}$ vitamins: A 210000 IU; D 40000 IU; E 2000 IU; B 30 IU; B 80 IU; B 400 mcg; B 45 mg; $\mathrm{B}_{12} 500 \mathrm{mcg}$; K $32.5 \mathrm{mg}$; H $500 \mathrm{mcg}$;

choline $1500 \mathrm{mg}$; folic acid $9.0 \mathrm{mg}$; Synthetic amino acids: methionine $7.50 \mathrm{~g}$; lysine $36.0 \mathrm{~g}$; threonine $5000 \mathrm{mg}$; mineral components: $\mathrm{Mn}$ $1500 \mathrm{mg}$; Zn $2250 \mathrm{mg}$; Co $8.0 \mathrm{mg}$; Se $6.0 \mathrm{mg}$;

$\mathrm{Cu} 500 \mathrm{mg}$; Fe $1800 \mathrm{mg}$; J $20 \mathrm{mg} ; \mathrm{Mg}$ (total) $1.0 \mathrm{~g}$, P (total) $27.5 \mathrm{~g} ; \mathrm{Na}$ (total) $25.0 \mathrm{~g}$, Ca (total) $122.0 \mathrm{~g}$; Other components: antioxidant 300 $\mathrm{mg}$; Betafin S, $3750 \mathrm{mg}$, Flavomycin $100 \mathrm{mg}$;

Ca panthotenate $200 \mathrm{mg}$; Pigor $757-4000 \mathrm{mg}$; brans $-4969000 \mathrm{mg}$. ${ }^{2}$ as above, without Flavomycin,

* Bactocell - contains strain Pedicoccus acidilactici MA18/5M

** BIO-MOS - contains cellular walls of Saccharomyces cerevisiae yeasts, strain 1026;

67, Clone Ki-S5 (Ki-67), and Monoclonal Mouse Anti-Proliferating Cell Nuclear Antygen (PCNA), Clone PC1 (PCNA). Samples were evaluated with a BX50 Olympus light microscope at $\times 400$ magnification.

The mitotic index (MI), i.e. the number of enterocytes in crypts, was determined by counting each time 100 cells in three replications. The height of epithelial cells in crypts was determined with the use of the AnalySIS 3.0 image analysis system. The results are presented as mean values for 10 measured cells. Ki-67 positive cells and PCNA positive cells were counted in three replications of up to 100 cells each. The results are presented as means over replications.

Based on the above results, the statistic calculations were carried out, using one-way analysis of variation. The significance of differences between the groups was calculated based on Duncan's multiple test. The computer package SPSS $10.0 \mathrm{pl}$ was used for calculation.

The following equation was used:

$\mathrm{y}_{\mathrm{ij}}=\mu+\mathrm{a}_{\mathrm{i}}+\mathrm{e}_{\mathrm{ij}}$

$\mathrm{y}_{\mathrm{ij}}$ - observed value,

$\mu$ - overall mean,

$a_{i}-$ effect of $i$-th feed addition,

$\mathrm{e}_{\mathrm{ij}}$ - random residual effect.

The study was approved by the institutional Ethics Committee.

\section{Results}

No significant differences in MI between the investigated groups were observed (Table 3, Plate V, Fig. 1). Compared to group C, the height of enterocytes in crypts in group 
Table 2. Experimental material

\begin{tabular}{|c|c|c|c|}
\hline \multirow{3}{*}{$\begin{array}{l}\text { Intestinal section/ investigated properties/ } \\
\text { staining }\end{array}$} & \multicolumn{3}{|c|}{ Group } \\
\hline & $\mathrm{C}$ & E1 & E2 \\
\hline & \multicolumn{3}{|c|}{ Number of analysed samples } \\
\hline \multicolumn{4}{|l|}{ Duodenum } \\
\hline MI*, enterocyte height: H-E & 30 & 23 & 12 \\
\hline Proliferation: Ki-67 & 24 & 20 & 15 \\
\hline PCNA & 27 & 21 & 15 \\
\hline \multicolumn{4}{|l|}{ Jejunum } \\
\hline MI, enterocyte height: H-E & 45 & 32 & 24 \\
\hline Proliferation: Ki-67 & 24 & 21 & 26 \\
\hline PCNA & 48 & 42 & 48 \\
\hline \multicolumn{4}{|l|}{ Ileum } \\
\hline MI, enterocyte height: H-E & 33 & 18 & 12 \\
\hline Proliferation: Ki-67 & 15 & 9 & 15 \\
\hline PCNA & 21 & 9 & 18 \\
\hline
\end{tabular}

*MI - mitotic index

H-E - haematoxylin - eosin

Table 3. Mitotic index (MI), veigth and proliferation of enterocytes in intestinal crypts

\begin{tabular}{|c|c|c|c|c|c|}
\hline \multirow{2}{*}{$\begin{array}{l}\text { Investigated properties } \\
\text { /intestinal section }\end{array}$} & \multicolumn{3}{|c|}{ Group } & \multicolumn{2}{|c|}{ Total average } \\
\hline & $\mathrm{C}$ & E1 & E2 & LSM & SEM \\
\hline \multicolumn{6}{|l|}{ Mitotic index (IM), $\%$} \\
\hline Duodenum & 5.7 & 6.1 & 5.0 & 5.6 & 0.930 \\
\hline Jejunum & 9.8 & 8.4 & 7.1 & 8.4 & 1.010 \\
\hline Ileum & 12.1 & 11.7 & 5.0 & 9.6 & 1.569 \\
\hline \multicolumn{6}{|l|}{ Enterocyte height, $\mu \mathrm{m}$} \\
\hline Duodenum & 18.65 & 18.71 & 18.85 & 18.74 & 0.298 \\
\hline Jejunum & $19.50 \mathrm{~A}$ & 20.77 & $21.74 \mathrm{~B}$ & 20.67 & 0.280 \\
\hline Ileum & $25.99 \mathrm{~A}$ & 24.78 & $23.67 \mathrm{~B}$ & 24.81 & 0.357 \\
\hline \multicolumn{6}{|l|}{$\mathrm{Ki}-67, \%$} \\
\hline Duodenum & 52.67 & 45.25 & 37.93 & 45.28 & 2.409 \\
\hline Jejunum & $55.46 \mathrm{~A}$ & $42.91 \mathrm{~B}$ & 51.85 & 50.07 & 1.857 \\
\hline Ileum & 40.67 & 49.78 & 34.73 & 41.73 & 2.690 \\
\hline \multicolumn{6}{|l|}{ PCNA, $\%$} \\
\hline Duodenum & 72.22 & 66.43 & 60.87 & 66.51 & 2.050 \\
\hline Jejunum & 67.81 & 70.55 & 65.77 & 68.04 & 1.268 \\
\hline Ileum & 59.91 & 48.56 & 53.28 & 53.91 & 2.465 \\
\hline
\end{tabular}

C - control group, (antibiotic - Flavomycin); E1 - experimental group, (probiotic - Bactocell);

E2 - experimental group, (prebiotic - BIO-MOS); A, B - significant differences at $P \leq 0.01$

${ }^{1}$ least square means - LSM; total average - average for all (three) groups; SEM - standard error of mean
E1 was greater in the jejunum $(11.49 \%) \quad(P \leq 0.01)$ and smaller in the ileum $(8.93 \%)$ $(\mathrm{P} \leq 0.01)$ (Table 3).

In the present study, the percentage of positive reactions during Ki-67 and PCNA labelling was not indicative of a regular dependency, and the obtained reactions were clearly pronounced (Table 3) (Plate V, Fig 2, Plate VI, Fig. 3). In group $\mathrm{C}$, the highest percentage of $\mathrm{Ki}-$ 67 positive cells was found in the jejunum. A smaller percentage of those cells was determined in the duodenum, and $\mathrm{Ki}-67$ positive cells were least likely to occur in the ileum. In comparison with group $\mathrm{C}$, the $\mathrm{Ki}-67$ reaction was less noticeable in groups E1 and E2. Significant differences $(P \leq 0.01)$ in proliferation activity were determined in the jejunum between groups $\mathrm{C}$ and $\mathrm{E} 1$. Proliferation activity was limited in group E1 in comparison with group $\mathrm{C}$, which can be regarded as an undesirable phenomenon (Table 3).

In the current study, the number of PCNA positive cells in groups E1 and E2 was below that reported in group C. Enterocyte proliferation in intestinal crypts was lower in the experimental groups than in the control group (with the exception of the jejunum in group E1), but the differences between groups E1, E2 and $\mathrm{C}$ were not statistically verified (Table 3). Regular dependencies were not determined with respect to the proliferation activity in crypts

in the investigated groups and segments of the small intestine. In group $\mathrm{C}$, the number of PCNA positive cells in the jejunum and the ileum was $6.11 \%$ and $17.95 \%$ lower than in the duodenum, respectively. In the group administered the probiotic (E1), the proliferation activity of enterocytes in the jejunum was $6.20 \%$ higher than in the duodenum, and it was $26.9 \%$ lower in the ileum than in the duodenum. Similar dependencies were reported in 
the group administered the prebiotic (E2) where proliferation was $8.05 \%$ higher in the jejunum than in the duodenum and $12.46 \%$ lower in the ileum than in the duodenum (Table 3).

\section{Discussion}

In a study investigating weaned piglets, Budiño et al. (2005) administered feed without additives as well as feed containing an antibiotic, a probiotic, a prebiotic and a synbiotic to discover that the density and length of duodenal villi was higher in pigs fed a diet with the prebiotic than in those receiving a diet with the probiotic. The above authors also concluded that in comparison with diets containing other additives, the structure and efficiency of intestinal villi was restored at a much faster rate in pigs administered the probiotic. Reiter (2006) observed no effect of the supplementation of diets for sows and piglets with a probiotic (Enterococcus faecium SF 68 NIMB 10415) on the morphology of the small intestine in young pigs. Nutritional factors, such as short-chain organic acids, may directly affect intestinal morphology, stimulating the proliferation of intestinal epithelial cells (Sakata et al. 1995; Ichikawa et al. 2002). In studies involving Lactobacillus acidophilus and Bifidobacterium spp., probiotic strains had no adverse effect on the morphology of the digestive tract, the liver and the pancreas (Babinska et al. 2005). Changes in glucose absorption were reported in young, growing pigs fed a probiotic-supplemented diet (Lodemann et al. 2006). The administration of probiotic strains enhanced glucose absorption. The authors are of the opinion that the above results confirm a positive effect of probiotics on animals.

Apoptosis and proliferation can be determined in the intestinal epithelium by immunohistochemical methods (Reed 1994; Kelman 1997). Ki-67 antigen expression is observed during all phases of the cellular cycle $\left(\mathrm{G}_{1}, \mathrm{~S}, \mathrm{G}_{2}\right.$ and $\mathrm{M}$ phase), and it does not take place in the quiescent $\left(\mathrm{G}_{0}\right)$ phase and in inactive cells. The antigen is decomposed when the cell enters the non-proliferative state (Scholzen and Gerdes 2000).

The PC10 monoclonal antibody facilitates the labelling of proliferating cells in healthy tissues (Hall 1990). This protein's expression is observed at the final stage of $G_{1}$ phase and at the initial stage of S phase. PCNA significantly contributes to the continuity of the cellular cycle. Oligonucleotides directed against PCNA inhibit the transition of cells to phase $\mathrm{S}$ of the cellular cycle. PCNA plays an important role in the life and death of cells, being an element of the DNA replication and repair mechanism. The absence or the low level of functional PCNA may lead to cell apoptosis (Kelman 1997; Paunesku et al. 2001). In cells, PCNA is nearly completely limited to the nucleus, it occurs in diffused, granular or mixed form (Hall 1990).

Micromorphometrical and immunohistochemical (PCNA) evaluation after the application of L-glutamine and/or nucleotides has shown that supplementation exerts a beneficial effect on the morphological and functional properties of intestinal mucosa (Domeneghini et al. 2004). Short-chain fatty acids were found to stimulate the proliferation of epithelial cells to a various degree: n-butyric acid $>$ propionic acid $>$ acetic acid. The source of those acids may be the fermentation process, but they can also be administered orally, or by intravenous, gastric and intestinal infusion (Sakata et al. 1995).

A morphological and immunohistochemical evaluation of the small intestinal mucosa of animals whose diets were supplemented with antibiotics, probiotics and prebiotics indicated that the administered additives had a varied effect on the mitotic index, enterocyte height and the proliferation capacity of crypt epithelium. Decreased enterocyte proliferation in crypt epithelium following the administration of probiotics or prebiotics necessitates further research in this area, although the absence of significant differences between groups (C, E1 and E2) may suggest that probiotics and prebiotics have no adverse effect on mucosal epithelial cells. 


\section{Acknowledgment}

The study was supported by the Committee of Scientific (KBN) (Project No. P06Z 026 25).

\section{References}

AOAC 1990: Official Methods of Analysis of the Associated of Official Analytical Chemists. Inc., Arlington, Virginia, $1141 \mathrm{p}$.

Babinska I, Rotkiewicz T, Otrocka-Domagała I 2005: The effect of Lactobacillus acidophilus and Bifidobacterium spp. administration on the morphology of the gastrointestinal tract, liver and pancreas in piglets. Pol J Vet Sci 8: $29-35$

Budiño FEL, Thomaz MC, Kronka RN, Nakaghi LSO, Tucci FM, Fraga AL, Scandolera AJ, Huaynate RAR 2005: Effect of probiotic and prebiotic inclusion in weaned piglet diets on structure and ultra-structure of small intestine. Braz Arch Biol Technol 48: 921-929

Domeneghini C, Di Giancamillo A, Savoini G, Paratte R, Bontempo V, Dell'Orto V 2004: Structural patterns of swine ileal mucosa following L-glutamine and nucleotide administration during the weaning period. An histochemical and histometrical study. Histol Histopathol 19: 49-58

Ekelund KM, Ekblad E 1999: Structural, neuronal, and functional adaptive changes in atrophic rat ileum. Gut 45: $236-245$

Hall PA, Levison DA, Woods AL, Yu CC-W, Kellock DB, Watkins JA, Barnes DM, Gillett CE, Camplejohn R, Dover R, Waseem NH, Lane DP 1990: Proliferating cell nuclear antigen (PCNA) immunolocalization in paraffin sections: An index of cell proliferation with evidence of deregulated expression in some, neoplasms. J Pathol 162: 285-294

Ichikawa H, Shineha R, Satomi S, Sakata T 2002: Gastric or recital instillation of short-chain fatty AIDS stimulates epithelial cell proliferation on small land large intestine in rats. Dig Dis Sci 47: 1141-1146

Kelman Z 1997: PCNA: structure, functions and interactions (Review). Oncogene 14: 629-640

Lata I, Juránková J, Doubek J, Přibramská V, Frič P, Ditě P, Kolář M, Scheer P, Kosáková D 2006: Labelling and content evaluation of commercial veterinary probiotics. Acta Vet Brno 75: 139-144

Lodemann U, Hubener K, Jansen N, Martens H 2006: Effect of Enterococcus faecium NCIMB 10415 as probiotic supplement on intestinal transport and barrier function of piglets. Arch Anim Nutr 60: 35-48

Manning TS, Gibson GR 2004: Prebiotics. Best Practice \& Research Clinical Gastroenterology 18: 287-298

Mccullogh JS, Ratcliffe B, Mandir N, Carr KE, Goodlad RA 1998: Dietary fibre and intestinal microflora: effect on intestinal morphometry and crypt branching. Gut 42: 799-806

Mroz Z 2001: Some developments on Dutch nutritional approaches to protect piglets against post-weaning gastrointestinal disorders in the absence of in-feed antibiotics. J Anim Feed Sci 10 (suppl. 1): 153-167

Paunesku T, Mittal S, Proctić M, Oryhon J, Korolev SV, Joachimiak A, Woloschak GE 2001: Proliferating cell nuclear antigen (PCNA): ringmaster of the genome. Int J Radiat Biol 77: 1007-1021

Piel C, Montagne L, Seve B, Lalles JP 2005: Inceeasing digesta viscosity using carboxymethylcellulose in weaned piglets stimulates ileal goblet cell numbers and maturation. J Nutr 135: 86-91

Polish Norm 1993: Polish Norm of Pigs Nutrition 1993 (Normy Żywienia Świń). Instytut Fizjologii i Żywienia Zwierząt PAN, Jabłonna (in Polish), pp. 1-87

Reed JC 1994: Mini-review: Bcl-2 and the regulation on programmed cell death. J Cell Biol 124: 1-6

Reiter K 2006: Effects of the probiotic Enterococcus faecium SF 68 (NIMB 10415) on the morphology of the intestinal mucosa of pigs. PhD Thesis. FU Berlin.

Rekiel A, Gajewska J 2006: Changes in the intestinal microflora of fatteners as affected by selected nutritional factors. Med Wet 62: 925-930

Sakata T, Adachi M, Hashida M, Sato N, Kojima T 1995: Effect of n-butyric acid on epithelial cell proliferation of pig colonic mucosa in short-term culture. Deut Tierarztl Woch 102: 163-164

Scholzen T, Gerdes J 2000: The Ki-67 protein: from the known and the unknown (Review). J Cell Physiol 182: 311-322

Schweiger M, Steffl M, Amselgruber WM 2003: Differential expression of EGF receptor in the pig duodenum during the transition phase from maternal milk to solid food. J Gastroenterol 38: 636-642

Van Nevel CJ, Decuypere JA, Dierick NA, Molly K 2005: Incorporation of galactomannans in the diet of newly weaned piglets: effect on bacteriological and some morphological characteristics of the small intestine. Arch Anim Nutr 59: 123-138

Vitini E, Alvarez S, Medina M, Medici M, De Budeguer MV, Perdigon G 2000: Gut mucosal immunostimulation by lactic acid bacteria. Biocell 24: 223-232 

Plate V

Rekiel A. et al.: Histological Changes ... pp. 67-72

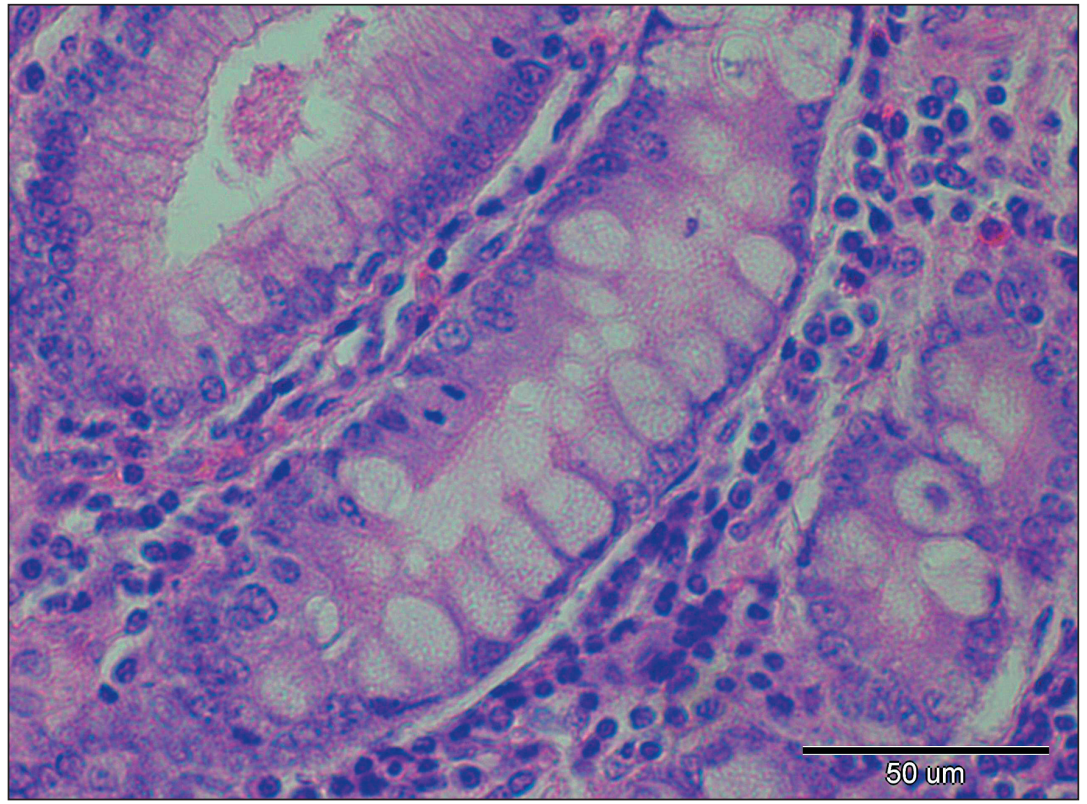

Fig. 1. Histological image of duodenal mucosa of E1 group of pigs. HE staining, magnification $\times 200$

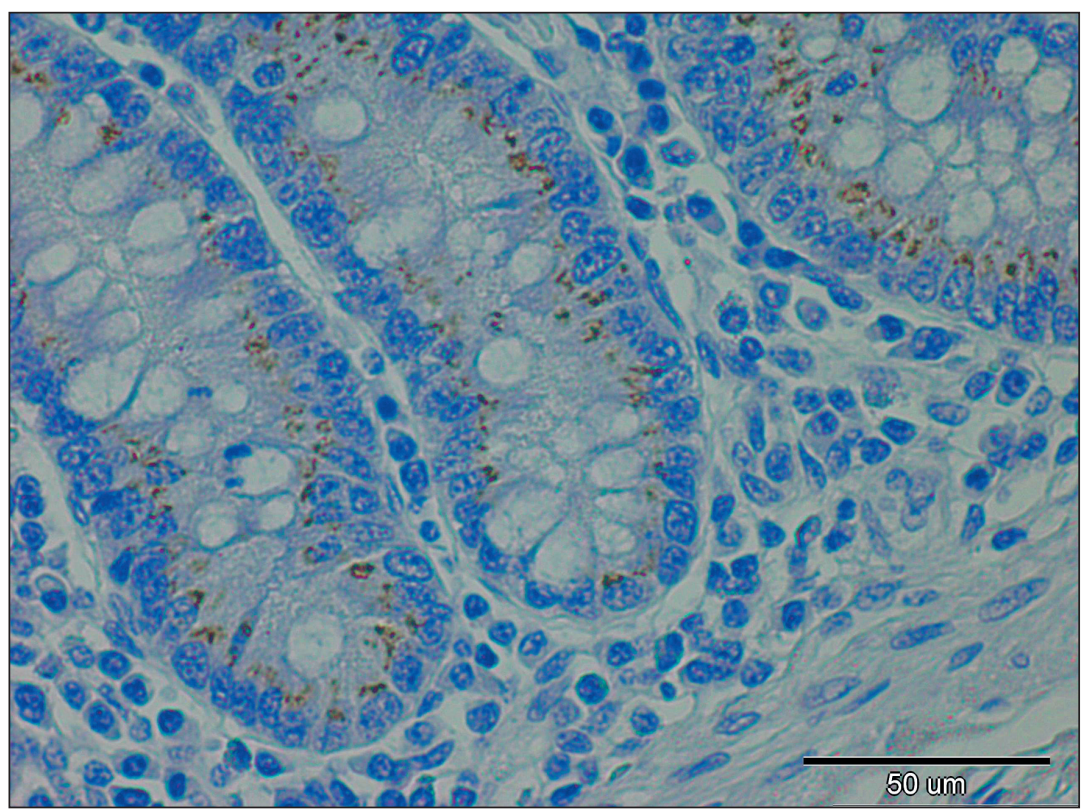

Fig. 2. Presence of Ki-67 positive cells in jejunal mucosa of E1 group of pigs. Immunohistochemical staining with the use of Ki-S5 monoclonal antibodies. Magnification $\times 200$ 


\section{Plate VI}

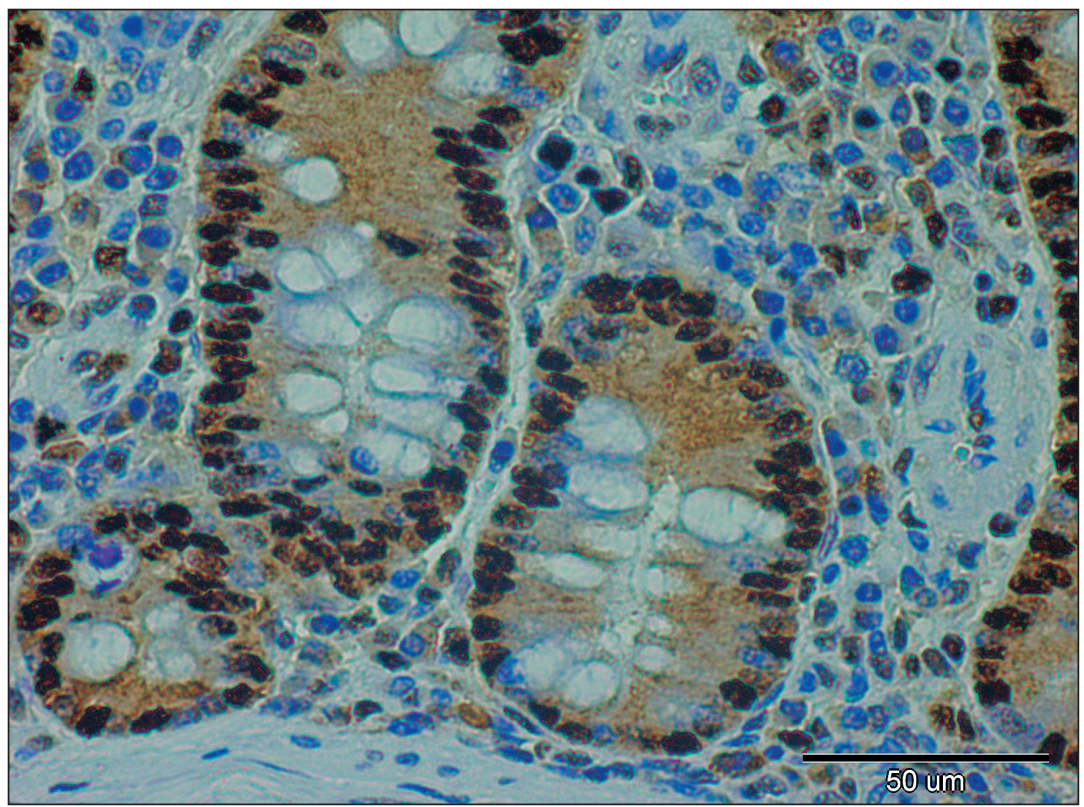

Fig. 3. Presence of PCNA positive cells in jejunal mucosa of E1 group of pigs. Immunohistological staining with the use of PC 10 monoclonal antibodies. Magnification $\times 200$ 